ppi $201502 Z U 4645$

Esta publicación científica en formato digital es continuidad de la revista impresa ISSN-Versión Impresa 0798-1406 / ISSN-Versión on line 2542-3185Depósito legal pp $197402 Z$ U34

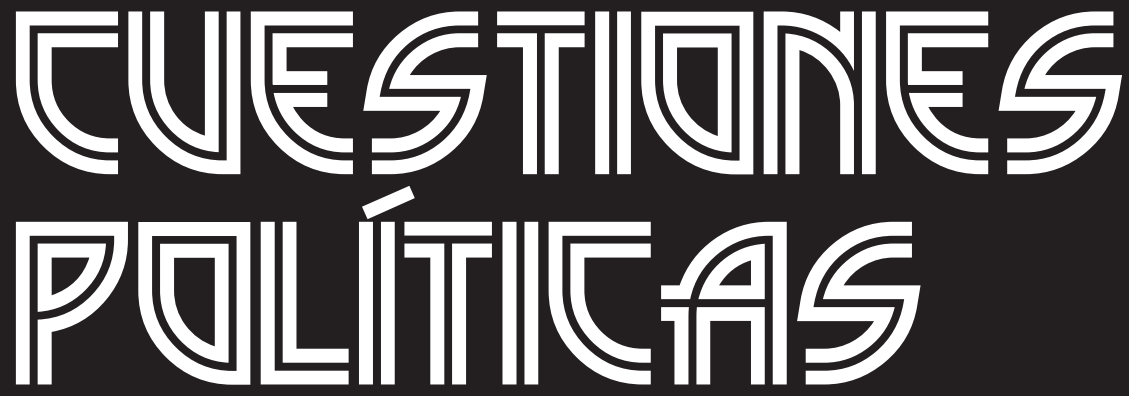

Instituto de Estudios Políticos y Derecho Público "Dr. Humberto J. La Roche" de la Facultad de Ciencias Jurídicas y Políticas de la Universidad del Zulia Maracaibo, Venezuela
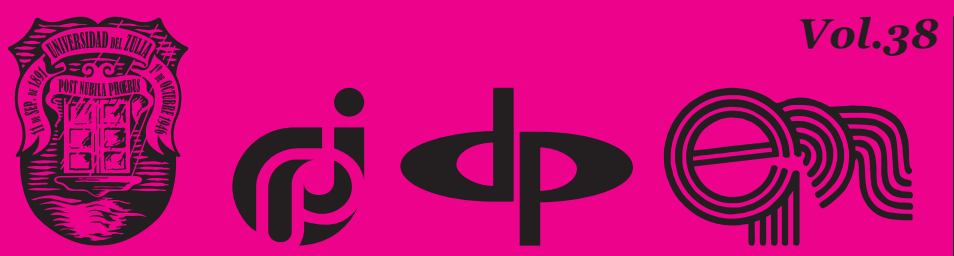

$N^{\circ}$ Especial 1era Parte 2020 


\title{
Trust Property: Legal Aspects
}

\author{
DOI: https://doi.org/10.46398/cuestpol.38e.25
}

\author{
Oksana Safonchyk * \\ Kateryna Hlyniana ** \\ Svetlana Mazurenko ***
}

\begin{abstract}
The article is devoted to the history of the emergence and formation of the institution of trust property in relation to various legal systems. The purpose of such a historical analysis of the institution of trust property is to find a possible place of this legal institution in domestic law, because trust property is a relatively new legal construct for Ukrainian law. The relevance of the article is to study the possibility of using the Anglo-American Trust Institute in Ukraine. The object of the study of this article is the legal relations arising from the institute of trust property. Methods of historicism, method of logic, method of analysis, method of synthesis, method of systematic research, and comparative-legal method were used in the study. The authors concluded that the institution of trust property goes back to one of the branches of English law. At the same time, the institution of trust is not inherent in the domestic legal system. However, since the 1990s, the domestic legislator has tried several times to introduce the relevant institution into Ukrainian legislation. So far,
\end{abstract} all of these attempts have failed.

Keywords: history of trust in Ukraine; property trust institute; property management; civil law; legal systems.

* Doctor of Law Science, Professor of Civil Law Department, National University «Odesa Law Academy». Odesa, Ukraine. ORCID ID: http://orcid.org/oooo-0001-6781-8219. Email: safonchyk.oksana@ gmail.

** Ph.D., Professor Assistant of Civil Law Department, National University «Odesa Law Academy». Odesa, Ukraine. ORCID ID: http://orcid.org/oooo-0002-1778-1021. Email: gkm2016@ukr.net

*** Ph.D., Professor Assistant of Intellectual Property and Corporate Law Department, National University «Odesa Law Academy». Odesa, Ukraine. ORCID ID: https://orcid.org/oooo-0oo1-5766-3225. Email: svetlana_mazurenko@ukr.net 


\section{Propiedad en fideicomiso: aspectos legales}

\section{Resumen}

El artículo está dedicado a la historia del surgimiento y formación de la institución del fideicomiso de propiedad en relación con varios sistemas legales. El objetivo fue efectuar un analisis histórico de la de la institución de la propiedad fiduciaria para encontrar un posible lugar a la misma en el derecho interno, porque la propiedad fiduciaria es una construcción legal relativamente nueva para la ley ucraniana. La relevancia del artículo está dada en estudiar la posibilidad de utilizar, con las adaptaciones del caso, el sistema Anglo-American Trust Institute en Ucrania. El ámbito del estudio de este trabajo son las relaciones jurídicas derivadas del instituto de fideicomiso patrimonial. En el estudio se utilizaron métodos de historicismo, método de lógica, método de análisis, método de síntesis, método de investigación sistemática y método legal comparativo. Los autores concluyeron que la institución de la propiedad fiduciaria se remonta a una de las ramas del derecho inglés. Al mismo tiempo, la institución de la confianza no es inherente al ordenamiento jurídico interno. Sin embargo, desde el decenio de 1990, el legislador nacional ha intentado varias veces introducir la institución pertinente en la legislación de Ucrania. Hasta ahora, todos estos intentos han fracasado.

Palabras clave: historia del fideicomiso en Ucrania; instituto de fideicomiso de la propiedad; administración de la propiedad; derecho civil; sistemas legales.

\section{Introduction}

An important factor in the development of the understanding of the concept of private law in Europe was the formation of the European community, reflecting integration tendencies first in Western Europe, and then, throughout the whole Europe (Kharytonov et al, 2019). The creation of the European Community has accelerated integration processes between European countries, in particular in the field of private law. Thus, the legal institutions previously inherent only in the Anglo-Saxon legal system began to actively penetrate into the continental legal system and vice versa. One of such institutions of Anglo-Saxon law is the institution of trust property.

Trust, which is one of the most popular instruments in common law countries, has in recent years been actively used in countries that have not traditionally defined this institution. Scientists and practitioners of continental law today reconsider their doctrinal approaches to this phenomenon and form a new vision of trust, and also create new legal 
instruments that allow to achieve similar goals as the trust. However, in different countries, such instruments may be called differently, but by their legal nature to be an analogue of a trust or, conversely, to have the same name, but legally be a completely different legal construction. In order to properly understand and use the classical trust and its derivatives that exist in different countries, it is necessary to determine its essence and legal nature. It should be added that this should be done gradually moving away from classical approaches that have existed for a long time in English law, as some of them are frankly outdated and often do not correspond to existing trends in the use of trust, even in the common law countries.

The main function of this institution is property management in favor of a predetermined person - the beneficiary. Trust relationships and related services are extremely diverse. Trusts are the most ancient form of property, representing a complex set of property management relationships based on a power of attorney, trusteeship or guardianship. A trust is a special relationship between legal entities or individuals regarding ownership, which is accompanied by the establishment of specific duties and responsibilities of persons managing the property, as well as special rights and privileges of the property owner that protect him from unauthorized and erroneous actions of the manager.

Thus, the purpose of the paper is a comprehensive study of the institute of trust property, in particular the contract of trust management of property as a form of its implementation, which must be achieved through a critical analysis of scientific civil doctrine, existing legal practice and the state of legislation in Ukraine and abroad.

The structure of the article is clear and understandable, and includes a consistent analysis of the historical aspects of the formation of the institution of trust property in England, where it originated, in other countries of Anglo-Saxon and continental law, as well as in Ukraine; research of the current state of the problems of the institute of trust; comparison of the institution of trust property with other related legal institutions; the state of the legal institution of trust property management in Ukraine and the prospects of trust property in Ukraine and in the world in general.

\section{Analysis of recent research}

Many domestic and foreign scientists were interested in the problems of applying the right of trust in recent years and long before; among them are Kozlov and Demushkina (1994), Peter (2019), Kaplan et al, (2019), Khokhlov (1995), Kulikova (1997), Mostovoj (1994), Ryabov (1996), Qu (2019), Shmygov (1997), Solovyanenko (1993), and Sukhanov (1995; 1996). 
Considering domestic scholars, the problem of providing property rigths was generally studied by Khokhlov (1995), Kozlov and Demushkina (1994), as well as Sukhanov $(1995 ; 1996)$ analyzed the pecularities of the management of another's property.

Not only domestic scholars, but also legal scholars from European countries studied the question of whether the institution of trust is suitable for the countries of the Romano-Germanic legal family. Thus, Peter (2019) studied whenever the trust is a suitable instrument or whether it would be more advisable to review the existing instruments, such as the Swiss family foundation or the fiducia, and to amend them accordingly.

Moreover, Kaplan et al (2019) studied the problem of use of trust concept in the Israel legal system as well as they review the provisions of the Israeli Trust Law. Besides, Qu (2019) has devoted his work to the use of trust law in court decisions in recent years, since the institution of trust was introduced into Chinese law only about twenty years ago. Also, an in-depth analysis of the institution of trust and the peculiarities of its application in English law was studied in the paper of Allan and Griffin (2018).

However, attempts to apply trust in the continental system of law continue among many scholars. Many questions still have not yet been investigated.

\section{Methodology}

In this research, the authors used general scientific methods, as well as special scientific methods. For example, general scientific methods are represented by the methods of historicism, method of logic, method of analysis, method of synthesis. Special scientific methods are represented by the comparative-legal method and the method of systematic research.

Thus, the method of analysis was used to assess the main components of the institution of trust for the possibility of introducing this institution in the national legislation. The method of synthesis was used by the authors to provide an opportunity to determine the place of the institution of trust in the overall picture of the legal system. Moreover, the method of historicism was used to determine the conditions for the formation of the institution of trust in the Anglo-American legal family. The method of logic helped to determine whether the Institute of Trust is suitable for the RomanoGermanic legal family and whether it is possible to apply this institution in Ukraine.

As for the special scientific methods, the method of systematic research was used in the study to show the experience of different countries 
concerning the attempts of implementation Anglo-Saxon Institute of Trust. Furthermore, among the special scientific methods, the method of comparative-legal should be mentioned. This method helps to compare the legislation of different countries due to the issue of place of Institute of Trust in legal system.

\section{Presentation of key research findings}

The development of trust is primarily associated with the evolution of property systems, and most importantly, with the personification of the rights of the owner, which leads to the emergence of the institution of inheritance, which is the direct basis for the trust.

The Institute of Property Management by the guardian in the interests of the owner, was formed in ancient times. There are documents evidencing the existence of the trust relations in Ancient Egypt, where, on the basis of guardianship and trust, the vast property of the Egyptian pharaohs and their children was managed.

Currently, there are two main concepts of trust relations, which have been consolidated in various systems of legislation:

a) trust in the Anglo-American (Anglo-Saxon) system of law.

b) trust management in the continental (Romano-Germanic, European) system of law.

Trust is a system of property and (or) physical relations between the founder of the trust, the trustee and the beneficiary, i.e. the person in whose interests trust transactions are made.

The concept of ownership in the Anglo-American system of law allows the separation (splitting) of property. Continental interpretation of ownership does not allow split ownership. Here the principle is established, according to which the number and content of property rights belonging to several persons in relation to the same thing can be determined by agreement (will) of participants in legal relations. Separation of ownership is allowed in space (horizontal and vertical) and in time. Authors from common law countries are critical of the well-known proprietor triad of Roman law and try to give a universal definition of property by compiling a kind of catalog of proprietary rights.

One of the definitions of ownership, developed in the Anglo-American doctrine, includes 11 elements: 
1) the ownership as exclusive physical control over the thing or as the right to exclusive use of it. If it cannot be in a physical possession (for example, because of its incorporeal nature), possession can be understood metaphorically or simply as the right to exclude other persons from any use of it.

2) the right to use, i.e. personal use of a thing when it does not include two subsequent powers.

3) the right to manage, i.e. the right to decide how and by whom the thing can be used.

4) the right to income, i.e. there are benefits arising from previous personal use of the thing and from permission to other persons to use it.

5) the right to alienation, consumption, waste at its discretion, change or destruction of a thing.

6) the right to security (guarantee (immunity) against expropriation).

7) the right to transfer the thing.

8) perpetuity i.e. lack of term of ownership.

9) the prohibition to use a thing to the detriment of others, i.e. the obligation to prevent the use of things harmful to others in a way.

10) liability in the form of a penalty, i.e. the possibility of rejection of things in the payment of debt.

11) residual nature (residual charter), i.e. the existence of rules to ensure the restoration of violated property rights.

A specific ownership right may cover only some of these elements. Consequently, several property rights may exist on the same property.

The most vivid features of this understanding of property are expressed in the trust, which is one of the most common institutions of Anglo-Saxon law, a special form of ownership of property. Its essence lies in the fact that the original owner - a settlor of the trust transfers the thing to the trustee so that he transfers this thing or the proceeds from its operation to the beneficiary, in the role of which both the founder of the trust and any third party. Both the trustee and the beneficiary are considered owners, but with different rights - the first has the right to manage (operate) the property transferred to him, the second retains the right to income and to get things back. The scope of the rights of each of the owners may vary depending on the conditions under which the trust is established (which may be determined by agreement, unilateral transaction or law). The trustee shall use the acquired property only in accordance with the purposes indicated by the founder. 
The trust institution (trust) is based on the peculiar medieval traditions of English law, later borrowed by the American legal system. The AngloSaxon rule of law, which has as its basis a system of judicial precedents, has a system of legal branches that is different from continental law. It distinguishes the so-called «equity», which arose in feudal times from the difference between the courts of general jurisdiction that gave rise to another branch of this right - common law, and the court of the Lord Chancellor. Within the framework of common law, it is practically impossible to protect the interests of the founder of trust in those cases when the trust acts contrary to its interests. Therefore, a way out of this situation is found using the "equity", since one of its aspects is the concept of a fiduciary obligation arising when one person acts exclusively in the interests of another person. Along with trust, real guarantees are also required for the true owner of the interest, if the trust turns out to be deceived.

The implementation of this complex, internally contradictory task is called upon to serve as the «equity», which, based on a case law, allows one to interpret the actions of the manager, based on the experience of previous or similar activities of other managers. The latter, in contrast to common law, recognizes the ownership of the founder of trust.

The construction of trust becomes indispensable where there is a need to hide the figure of the real owner, obscuring it by the nominal (trust) owner. The main goal of developing the institution of trust was to circumvent the prohibitions for some entities to be owners of certain types of property. For a long period of time, the trust existed for the preservation and redistribution of property within the family. For example, in accordance with medieval English law, land could not be transferred to any person by will, but passed after the death of the owner exclusively to his heir by law. However, when transferring the land to the trust, the owner had the right to independently appoint a beneficiary who would manage the land after his death, and thereby circumvented the prohibition.

This explained the creation of fiction - the consolidation of ownership of a person who did not actually use its consequences, the creation of a figure of a nominal owner. The relations between such a nominal owner and beneficiary, to which the real benefits should belong, are paramount. Naturally, such relations cannot have a purely formal character; otherwise, circumvention of the law becomes obvious. Hence the fiduciary, trusting nature of the relationship.

The above features of the institution of trust do not allow using it unchanged in countries with a continental system of law, where ownership is considered as a system of prerogatives of the owner: possession, use, and disposal. Therefore, lawyers of the countries of continental law will see the institution of representation where English or American lawyers see trust property. 
However, the experience gained over the centuries of the institution of trust can be extremely useful for the development of the institution of trust management. In all common law countries, the legislator has done a great deal of codification and legislative regulation of trust relations, since case law, as a set of court decisions in specific cases, cannot serve as a reliable legal basis for modern trade. For example, in England, general laws regulate a significant part of such legal relations, and acts are codified. Case law applies to the extent not regulated by laws and not contrary to them.

As for Ukraine and some other countries of the continental legal system, the use of the trust in civil law relations is problematic. The first optimism about the implementation of the trust in European legal systems was soon replaced by doubt and skepticism caused by restrictions on the disposal of property, a special legal regime that violates the foundations of the Romano-German legal system and several other factors.

As was mentioned above the concept of trust is a unique historical product of the dualistic legal system of England. Although there is some legislative regulation of trusts, the complex set of rules, which govern trusts in English law, comes from centuries-old case law.

Liechtenstein was the first country in continental Europe to have established the institution of trust in the domestic law. However, the motivation for establishing trusts in Liechtenstein's jurisdiction has now changed: if the founders of the trusts wanted to save on taxes, now they are being established to protect assets and to plan inheritance. As a result, the trusts themselves, their types, have changed.

Germany is not a party to The Hague Convention on the Law Applicable to Trusts and on their Recognition (1985); it does not recognize foreign trusts. German law does not accept the institution of trust, as well as testamentary trust is also impossible. Instead, the legislator uses other mechanisms familiar to German law for succession planning (Foreign law trust: how does it work and why is it believed in?, 2016).

In the modern world, the construction of the divided property is most clearly represented by the Anglo-American Trust. The influence of the Anglo-American trust on the private law of the whole world is that the legal systems that are most resistant to external influences must nevertheless determine what exactly is the incompatibility of the trust with the principles of civil law.

If in the 1930s the trust was compared with the bond ownership or Fiducia (Fiducia Cum Amico, 2020) of Roman law, with usufruct, with German fiduciary property (Treuhand) and the Lombard Salman, the executor of the will, which even saw the pan-European predecessor of the English trust, then in the 1950 - 1960 years comparativists convincingly refuted these parallels by showing that they rather reveal insurmountable 
differences between systems rather than provide examples of the presence of "trust-like" entities in civil law.

The implementation of a trust in the continental system of law can have such negative consequences:

- The trust allows for a long time to withdraw property from circulation, violating the interests of creditors and heirs.

- The trust manager is not interested in obtaining the maximum income from the property of the trust.

- The management of the trust is subordinate to the tasks of preserving the property, and not increasing it, so the manager is not recommended to enter risky commercial enterprises that promise high returns.

- The trust creates uncertainty in the distribution of assets in cash, which can mislead the subjects of turnover and tax authorities.

- The trust gives the beneficiary unjustified privileges concerning the creditors of the trust.

- The trust creates a special regime of property, violating the general principles and rules of law.

Of the main obstacles to the reception of trust in the continental system of law, we can name the following:

- Unitary ownership structure.

- A closed list (numerus clausus) of property rights.

- Freedom of disposal of the owner.

- The principle by which the debtor is liable for obligations with all his property.

- The principle of equal standing of creditors (par condicio creditorum).

- Protection of a bona fide acquirer.

The problem of the last two is due to the fact that the beneficiary is vested with the right to pursue the property of the trust, unlawfully alienated by the manager, in the hands of third parties (tracing).

Benefits of the beneficiary concerning third parties are generally referred to as "equitable ownership". The principle of separating the property of the trust from other property of the trustee trust has the same basis since from equity; the property of the trust does not belong to it. At the same time, in terms of English law, the beneficiary (which may not even exist in the 
trust) does not compete with the trustee ownership, but can only require him to comply with the requirements of the constituent documents of the trust. However, from civil law, such a right aimed at the trustee not as an individual, but as the owner of the property of the trust, reinforced by the possibility of presenting claims against third parties, acts as the right to a thing. This contradicts the principle of an exhaustive list of property rights: the civil law system cannot recognize a trust within the framework of an established set of rights to things.

Unity of ownership also acts as the basis of the principle by which the debtor is liable for obligations with all his property. Separation of the trust property from the trustee's property, making the trust inaccessible to the personal creditors of the trust owner, from civil law creates two assets for one person.

As an owner, a trustee cannot act in his interests but is obliged to use the property for the purposes established by the constituent documents of the trust. The owner of the trust must obey the constituent documents of the trust, and in case of doubt, follow the instructions of the court. From a formal (legal) point of view, he does not have his interest, which is incompatible with the very concept of property and denies the nature of genuine law in his position. Restrictions on the disposal and external control of trustee actions also contradict the principle of unity of ownership.

So mentioned above specificity of the trust does not allow Ukrainian civil law to accept this institution.

An important stage in the establishment of a trust in countries with a contingent legal system was The Hague Convention on the Law Applicable to Trusts and on their Recognition (1985). The subsequent projects for the reception of trust in several civil law countries: France, Belgium, the Netherlands, and Italy - it was not the English model of the trust that was taken as a model, but the constructions known in a mixed legal system. Meanwhile, as we have seen, not a single "mixed" legal system has so far been able to arrive at a final definition of the subject of ownership in a trust, and the trust in these countries remains an artificial and alien formation. Failure to identify the institution with its concrete historical embodiment in the English model means eroding the concept of trust.

\section{Conclusions}

- Thus, trust property is an institution of law that has historically originated in the Anglo-Saxon system of law. Its emergence is due to the peculiarities of the Anglo-Saxon legal system. In particular, this institution arose within the concept of the split property, which is not inherent in the continental legal system. 
- One of the main postulates of the continental legal system is the impossibility of establishing two identical property rights to the same property. Property rights in its continental, including Ukrainian, sense cannot be «split»: it is either completely retained by the owner or completely lost by him. With any other approach, there is an unresolved conflict of rights of owners, each of whom wishes to dispose of their property at its own discretion.

- Therefore, it cannot be implemented in the legislation of the countries of the continental legal system due to the presence of conceptual differences in approaches to understanding ownership of these legal systems.

- The legal analysis of the trust and trust management illustrates that these institutions have much in common: the economic goal of making a profit from property, the separation of management and profit functions between different entities, the legal status of the manager and trustee.

- However, the differences between the Anglo-American and civil law institutions are more than significant. The institution of the trust is unique and can fully function only in the system of precedent AngloAmerican law that created it.

- The implementation of the trust in the domestic law of civil law countries is not possible due to several circumstances: the denial of the concept of split property; the principle of numerous clauses; the impossibility of referring the trust to the full extent to either property or liability law.

- However, the study of the institution of a trust may contribute to the improvement of the legal regulation of the domestic institution of trust management of property.

\section{Bibliographic References}

ALLAN, Gregory; GRIFFIN, Stephen. 2018. "Corporate personality: utilising trust law to invoke the application of the concealment principle" In: Legal Studies, Issue 38, No. 1, p.p. 79-102. Available online. In: https:// www.cambridge.org/core/journals/legal-studies/article/corporatepersonality-utilising-trust-law-to-invoke-the-application-of-theconcealment-principle/BFF43FC9C596971DFC30565C36C05577/. Consultation date: $26 / 04 / 2020$. 
Oksana Safonchyk, Kateryna Hlyniana y Svetlana Mazurenko
394 Trust Property: Legal Aspects

FIDUCIA CUM AMICO. 2020. Brocardi.it. Available online. In: https: //www. brocardi.it/F/fiducia-cum-amico.html. Consultation date: 15/04/2020.

FOREIGN LAW TRUST: HOW DOES IT WORK AND WHY IS IT BELIEVED IN? 2016. Law. Available online. In: https://pravo.ru/news/ view/129986/. Consultation date: 15/04/2020.

KAPLAN, Alon; EYAL, Layt; LIBERMAN, Maytal. 2019. "Israel: the trust law and the Hekdesh deed" In: Trusts \& Trustees. Vol. 25, No. 6, pp. 673676. Available online. In: https://academic.oup.com/tandt/articleabstract/25/6/673/5539954. Consultation date: 20/04/2020.

KHARYTONOV, Evgen; KHARYTONOVA, Olena; KHARYTONOVA, Tetiana; KOLODIN, Denis; TOLMACHEVSKA, Yuliia. 2019. "Human rights as the basic value of the concept of private law in modern Europe" In: Amazonia Investiga, Vol. 8, No. 20, pp. 477-485. Available online. In: https://www.amazoniainvestiga.info/index.php/amazonia/article/ view/177. Consultation date: 20/04/2020.

KHOKHLOV, S. 1995. "Ownership and other property rights" In: Bulletin of the Supreme Arbitration Court of the Russian Federation. Vol. 8, pp. 98-107.

KOZLOV, A; DEMUSHKINA, E. 1994. "Management of another's property: Problems and solutions" In: Bulletin of the Bank of Russia. Vol. 1, pp. 284-287.

KULIKOVA, L. 1997. “Trust management of property” In: Business, attorney, Vol. 2, pp. 145-149.

MOSTOVOJ, P. 1994. “Trust is extremely convenient" In: Economics and Life. Vol. 5, pp. 79-83.

PETER, Natalie. 2019. "Introduction of a trust law in Switzerland" In: Trusts \& Trustees, Vol. 25, No. 6, pp. 578-586. Available online. In: https:// academic.oup.com/tandt/articleabstract/25/6/578/5539960?redirecte $\mathrm{dFrom}=$ fulltext. Consultation date: 20/04/2020.

QU, Jian. 2019. "Trust law in Chinese courts: judicial decisions as data 20012017"In:Trusts \&Trustees. Vol. 25, No. 7, pp. 761-775. Availableonline.In: https://academic.oup.com/tandt/article-abstract/25/7/761/5536352. Consultation date: 26/04/2020.

RYABOV, A. 1996. “Trust in Russian law” In: State and law. Vol. 4, pp. 113-121.

SHMYGOV, S. 1997. “Contractual relations in trust” In: Stocks and bods market. Vol. 13, pp. 65-75. 
SOLOVYANENKO, N. 1993. "Trust construction trust and legal regulation of market relations in Russia" In: Management and law. Vol. 7, pp. 23-42.

SUKHANOV, E. 1995. "Property managamemt or trust" In: Economics and life. Vol. 6, pp. 323-327.

SUKHANOV, E. 1996. "Trust management of property" In: Household and law. Vol. 11, pp. 25-29.

THE HAGUE CONVENTION ON THE LAW APPLICABLE TO TRUSTS AND ON THEIR RECOGNITION. 1985. Hague Conference on Private International Law. Available online. In: https://www.hcch.net/en/ instruments/conventions/full-text/?cid=59. Consultation date: 26/04/2020. 


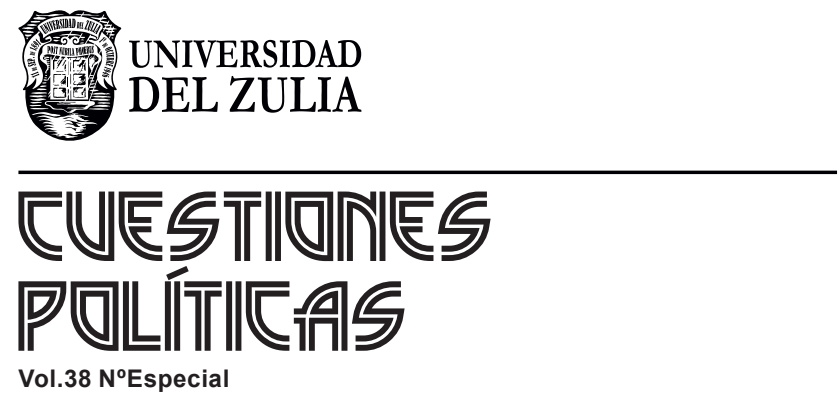

www.luz.edu.ve 